\title{
Comparative Analysis of Soil Properties for Influence of Fertilizers using Remote Sensing Techniques
}

\author{
Vipin Y. Borole \\ Department. of Computer Science \& Information \\ Technology, Dr. Babasaheb Ambedkar Marathwada \\ University, Aurangabad, Maharashtra, India
}

\author{
Sonali B. Kulkarni \\ Department.of Computer Science \& Information \\ Technology, Dr. Babasaheb Ambedkar Marathwada \\ University, Aurangabad, Maharashtra, India
}

\begin{abstract}
Soil properties assessment is critical for agricultural, environmental management. Regular soil assessment laboratory methods are very time consuming and expensive. For this work ground based remote sensing methods using spectroscopy technique was used in laboratory for soil properties assessment. Whereas spectral signature obtaining the diffused reflectance from spectroradiometer data is used. The different statistical methods are used for get the quantitative results of the acquired spectral data. By using this innovative technique comparative analysis of collected soil samples in premonsoon and postmonsoon was execute for finding the influence of fertilizers in different seasons. Soil samples are collected in context of surface and subsurface in premonsoon and post monsoon season for analyzing the influence of fertilizers on soil quality in banana and cotton crops soil. Soil properties analysis including chemical properties like nitrogen, phosphorus, potash, carbon, $\mathrm{pH}$ as well as physical properties like sand, silt, clay, soil organic matter (SOM), moisture were measured. The major difference is found in the availability of soil contents are higher in premonsoon season than postmonsoon season soil samples. Thus, this study implied that spectroscopic ground based remote sensing data based method provided great potential to analyze the soil properties.
\end{abstract}

\section{General Terms}

Comparative analysis of soil properties using remote sensing

\section{Keywords}

Crops, Chemical properties, Fertilizers, Physical properties, Remote Sensing, Spectroradiometer

\section{INTRODUCTION}

Soil is most important natural resource for agriculture field and spatiotemporal assessment of soil properties is important for sustainable agricultural management. In the agriculture field the soil properties are dynamic due to human activities, different agricultural practices and global climatic change it may change [1]. Soil nutrients are the major source of soil fertility that helps for plant growth as well as yield production. In the agriculture field farmers used the organic, chemical or mixed fertilizers for fulfilment of nutrients. But accurately use of fertilizers based on the required amount for a certain site or type of crop and soil has always remained a challenge [2]. Improper fertilizers management, tillage practices, heavy use of chemical fertilizers, it can be affect the soil quality and soil fertility. However, rapid and reliable assessment of soil properties has become one of great challenges in environmental monitoring and agricultural fertilizers management. In Conventional laboratory analysis methods large number of soil samples and chemical analysis are required for identifying soil properties. Laboratory analyses of spatial soil variability are time and cost consuming and it generate chemical wastes that can be environmentally hazardous [3]. Hence, developing new methodologies is necessary for soil property monitoring. Remote sensing using reflectance spectroscopy methods provide new perspectives for rapid soil properties assessment $[4,10]$. Hyperspectral remote sensing non-imaging spectroradiometer data provide high resolution spatial data in a large number of continuous spectral bands in the VNIR-SWIR region (350-2500 $\mathrm{nm}$ ). In the laboratory, the soil reflectance measurements are made under controlled conditions for detection physical and chemical properties of soil and soil reflectance [5]. Different fertilizers treatment and their influence on soil spectral characteristics can be analyzed in an efficient way. The reflectance curve using absorption feature parameters for identification of suitable spectral band for soil assessment of such soil with soil physicochemical parameters from organic, chemical and mixed fertilizers treatment were applied for banana and cotton crops. The effects of chemical fertilizer on nutrients loss from surface soil is high than Organic manure application in post monsoon season soil sample due to the rainfall and runoff. Thus, the amount of organic inputs should be considered to minimized nutrients losses through surface soil [6]. The comparative analysis of two different season soil samples with different fertilizers treatment applied for banana and cotton crops were collected for finding the influence of fertilizers on soil properties. Soil samples are collected in two different season pre monsoon (first week of June) and post monsoon (first week of November) and analysis of physical and chemical soil properties in two season. In this regard, more attention should be given to the analysis of reflectance spectra obtained from soils containing various amount of soil content. Taking all factors into consideration, present exploration was carried out the laboratory spectra using spectroradiometer. Therefore remote sensing spectral analysis resulted in reducing computational effort, increasing the speed of computational processing and finally obtained the optimum performance in estimating soil properties [10].

\section{STUDY AREA}

The study is carried out in Raver Tahsil of Jalgaon District in Maharastra, which is located between Lat: $21^{\circ} 12^{\prime} 30^{\prime}{ }^{\prime} \mathrm{N}$,

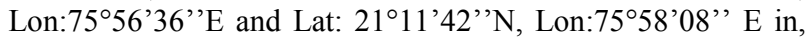
India with GPS information.

\section{MATERIAL AND METHODS}

For the comparative analysis soil samples are collected from Organic, Chemical and Mixed fertilizers treatments used for banana and cotton crops sites in two different season. In premonsoon (First week of June) season 50 soil samples were collected from 25 different locations. Each location containing 2 soil sample one from surface $(5-20 \mathrm{~cm})$ and other from subsurface $(30 \mathrm{~cm})$. As well as, in post-monsoon (First week of November) season 60 soil samples were collected from 30 
different locations where different fertilizers treatment used for different crops. Each location containing 2 soil sample one from surface $(5-20 \mathrm{~cm})$ and other from subsurface $(30 \mathrm{~cm})$. Collected soil samples are classified according to season, fertilizers treatment and cropwise like Premonsoon Organic Cotton (PROC), Postmonsoon Organic Cotton (POOC), Premonsoon Mixed Cotton (PRMC), Postmonsoon Mixed Cotton (POMC), Premonsoon Organic Banana (PROB), Premonsoon Mixed banana (PRMB), Premonsoon Chemical Banana (PRCB), Postmonsoon Organic Banana (POOB), Postmonsoon Mixed Banana (POMB), Postmonsoon Chemical Banana (POCB). At the time of soil sample collection, collected soil samples are hand crushed the soil bulk. The soil were sieved through $2-3 \mathrm{~mm}$ sieve then air dried the soil sample in the shadow of tree for 1-2 hours. Then divide the soil in four groups and pick-up any two part of soil which are placed in the cross of each in the group of four soil sample [2]. Keep the collected soil sample in the airtight zip lock bag and transport to the lab for spectral data acquisitions.

\subsection{Spectral Data Acquisition}

ASD Field Spec4 non-imaging spectroradiometer having spectral range (350- $2500 \mathrm{~nm}$ ) is used for data acquisition. As it acquires data in many narrow wavelength bands, it allows the use of almost continuous data in studying the Earth's surface [7-9]. Spectral representation of soil samples data is shown in figure 1 in the form of spectral signature. These spectral signatures are acquired using ASD FieldSpec4 Spectroradiometer (Analytical Spectral Devices Inc.,USA). Spectroradiometer gives the output in the form of continuous spectral response curve is referred to as the spectral signature of collected soil samples [15-16,19-24]. Reflectance spectroscopy provides an alternate method to classical physical and chemical laboratory soil analysis for the estimation of a large range of soil properties. Spectroradiometer giving minimal sample preparation, fast analysis, cost-effective to analyze a single or batch of samples, several constituents can be determined simultaneously, no destruction of samples, no hazardous chemical used, and results can be accurate and fast [12-14]. After data collection, approximate ten spectral signatures are acquired for every sample. Then calculate the mean of every ten spectral signature using View Spec Pro version 6.2 software. Generate the statistic data of each mean sample and process data using View Spec Pro 6.2 software [17$18,25,27]$.

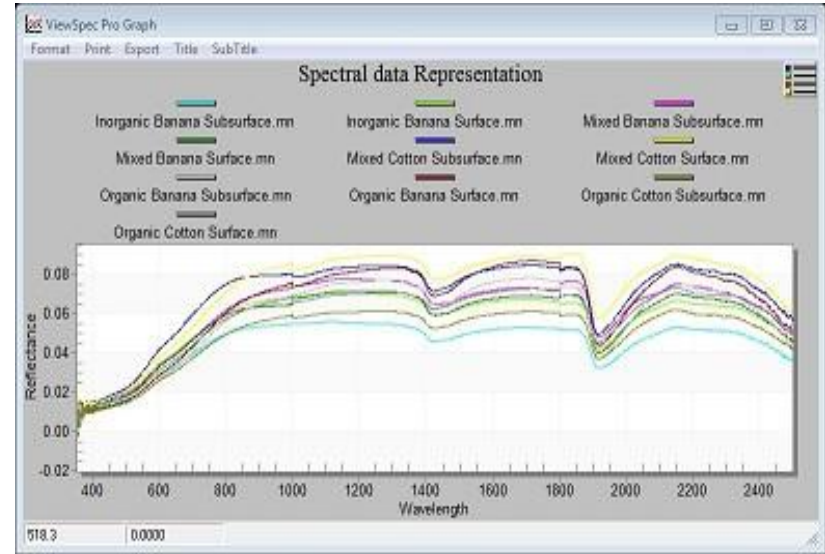

Figure 1. Spectral representation of collected soil samples

The spectral signature representation of collected soil sample is represented in figure 1. All spectral signatures are acquired from Field Spech4 Spectroradiometer and View Spec Pro software were used for spectral signature representation and processing.

\section{RESULT}

For the comparative analysis of premonsoon and postmonsoon season collected soil spectral data are processed and analyze physical and chemical soil properties. Soil properties calculated from statistical data which is collected from spectral signature. Spectral signatures are export for getting statistical data then it process using Microsoft Excel. Different chemical soil parameters are analyze on different spectral absorption range. The average is calculated for each properties of particular spectral range of different fertilizers treatment used soil sample from the surface and subsurface in premonsoon and postmonsoon season.

\subsection{Soil Sample analysis for Chemical Properties}

Soil sample analysis for chemical properties for finding the effect of fertilizers in different season $\mathrm{pH}$, Carbon, Nitrogen $(\mathrm{N})$, Phosphorous $(\mathrm{P})$, Potash $(\mathrm{K})$ are find out. These chemical properties are most important in soil fertility and productivity. Table 1. shows quantitative surface soil analysis of chemical properties for cotton crops with different fertilizers treatments used in premonsoon and postmonsoon season.

Table no.1 Surface Cotton soil sample analysis for Chemical Properties

\begin{tabular}{|c|c|c|c|c|c|}
\hline $\begin{array}{c}\text { Season/ Soil } \\
\text { Properties }\end{array}$ & $\mathbf{p H}$ & Carbon & Nitrogen & Phosphorous & Potash \\
\hline $\begin{array}{c}\text { Postmonsoon } \\
\text { Organic Cotton } \\
\text { (POOC) }\end{array}$ & 0.061 & 0.067 & 0.067 & 0.066 & 0.065 \\
\hline $\begin{array}{c}\text { Premonsoon } \\
\text { Organic Cotton } \\
\text { (PROC) }\end{array}$ & 0.104 & 0.128 & 0.130 & 0.126 & 0.112 \\
\hline $\begin{array}{c}\text { Postmonsoon } \\
\text { Mixed Cotton } \\
\text { (POMC) }\end{array}$ & 0.075 & 0.083 & 0.085 & 0.082 & 0.082 \\
\hline
\end{tabular}




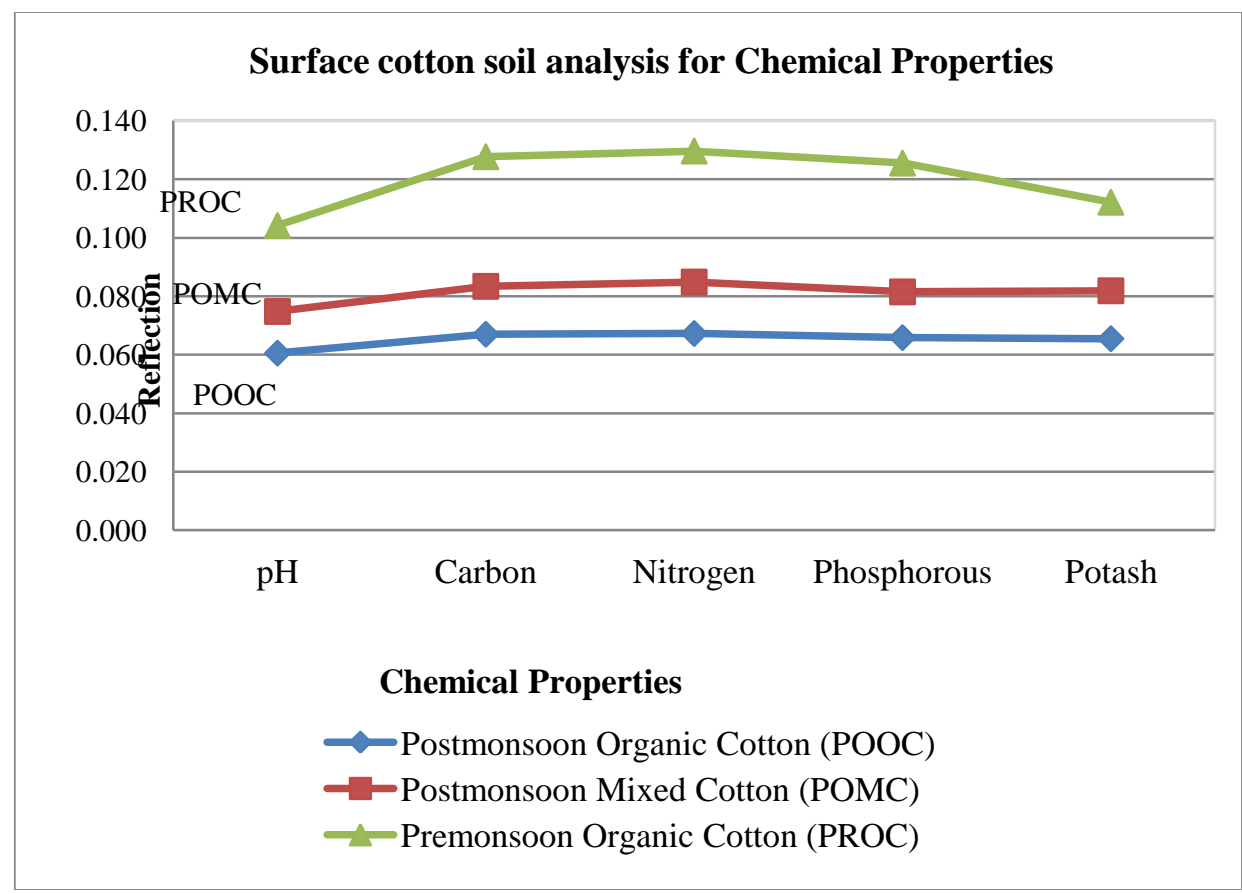

Fgure 2. Graphical representation of Surface cotton soil analysis for Chemical Properties

Graphical representation of Surface cotton soil analysis for Chemical Properties shown in figure 2. In this category of soil analysis premonsoon organic cotton soil sample having more reflection means more content availability than postmonsoon mixed cotton and postmonsoon organic cotton soil samples.
Subsurface soil analysis of chemical properties for cotton crops with different fertilizers treatments used in premonsoon and postmonsoon season quantitative representation shown in table 1

Table 2. Subsurface Cotton soil sample analysis for Chemical Properties

\begin{tabular}{|c|c|c|c|c|c|}
\hline $\begin{array}{c}\text { Season/ Soil } \\
\text { Properties }\end{array}$ & pH & Carbon & Nitrogen & Phosphorous & Potash \\
\hline $\begin{array}{c}\text { Postmonsoon } \\
\text { Organic Cotton } \\
\text { (POOC) }\end{array}$ & 0.051 & 0.057 & 0.057 & 0.056 & 0.055 \\
\hline $\begin{array}{c}\text { Premonsoon } \\
\text { Organic Cotton } \\
\text { (PROC) }\end{array}$ & 0.10 & 0.126 & 0.127 & 0.125 & 0.109 \\
\hline $\begin{array}{c}\text { Postmonsoon } \\
\text { Mixed Cotton } \\
\text { (POMC) }\end{array}$ & 0.071 & 0.078 & 0.078 & 0.076 & 0.076 \\
\hline
\end{tabular}

There is no more difference is recorded in surface and subsurface soil sample for chemical properties analysis but there are more reflection is recorded in premonsoon than postmonsoon season soil samples. 


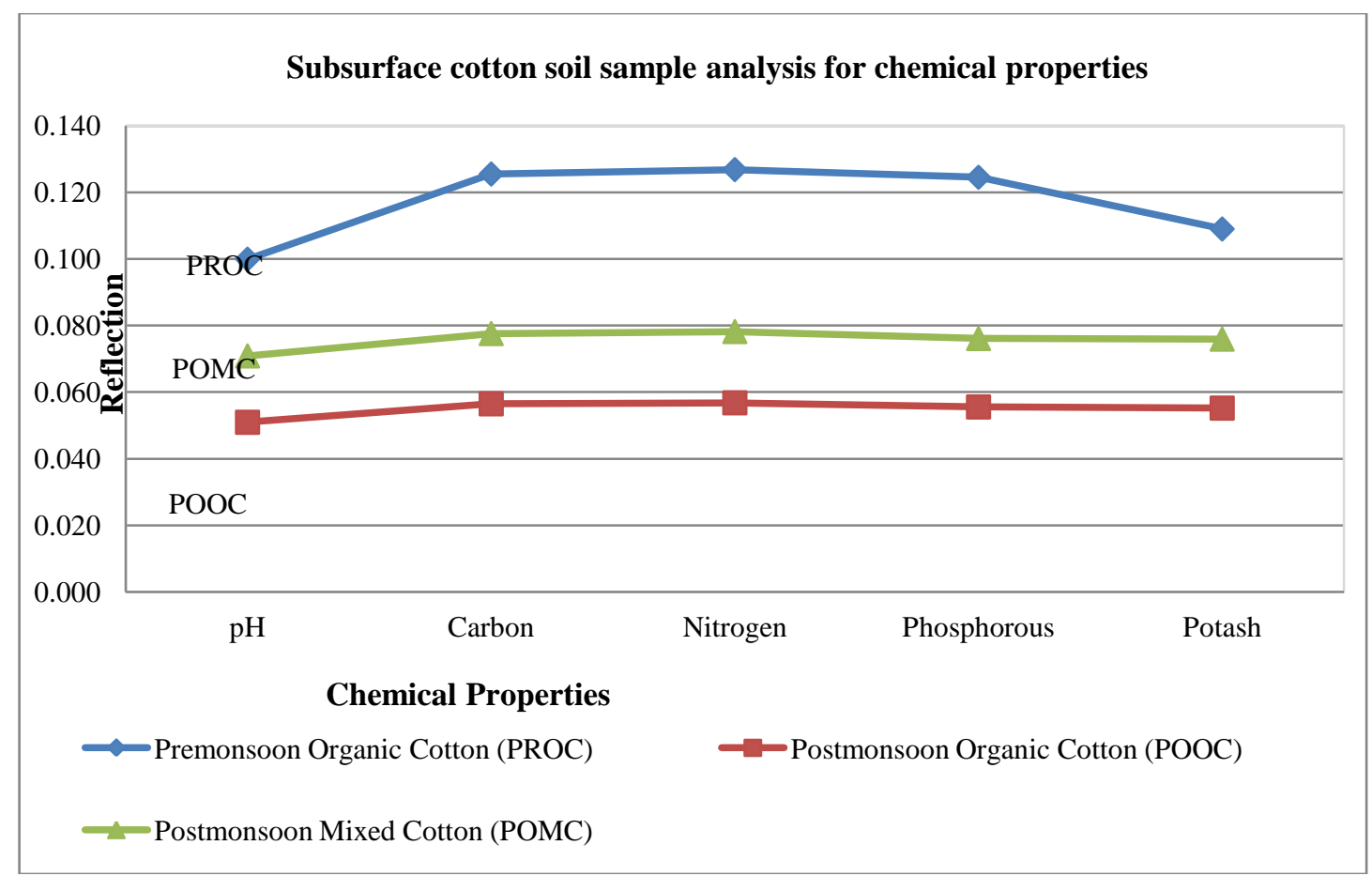

Figure 3. Graphical Representation of Subsurface cotton soil sample analysis for chemical properties

Figure 3 shows subsurface soil analysis for chemical properties. In this representation of soil analysis Premonsoon organic cotton having more reflection means more content

Table 3. Surface Banana soil sample analysis for Chemical Properties

\begin{tabular}{|l|c|c|c|c|c|}
\hline $\begin{array}{l}\text { Season/ Soil } \\
\text { Properties }\end{array}$ & pH & Carbon & Nitrogen & Phosphorous & Potash \\
\hline $\begin{array}{l}\text { Postmonsoon } \\
\text { Organic Banana } \\
\text { (POOB) }\end{array}$ & 0.060 & 0.067 & 0.068 & 0.065 & 0.066 \\
\hline $\begin{array}{l}\text { Premonsoon } \\
\text { Organic Banana } \\
\text { (PROB) }\end{array}$ & 0.117 & 0.140 & 0.140 & 0.139 & 0.123 \\
\hline $\begin{array}{l}\text { Postmonsoon } \\
\text { Mixed Banana } \\
\text { (POMB) }\end{array}$ & 0.063 & 0.070 & 0.071 & 0.068 & 0.068 \\
\hline $\begin{array}{l}\text { Premonsoon Mixed } \\
\text { Banana (PRMB) }\end{array}$ & 0.079 & 0.090 & 0.092 & 0.090 & 0.081 \\
\hline $\begin{array}{l}\text { Postmonsoon } \\
\text { Chemical Banana } \\
\text { (POCB) }\end{array}$ & 0.045 & 0.049 & 0.049 & 0.048 & 0.048 \\
\hline $\begin{array}{l}\text { Premonsoon } \\
\text { Chemical Banana } \\
\text { (PRCB) }\end{array}$ & 0.088 & 0.105 & 0.106 & 0.104 & 0.093 \\
\hline
\end{tabular}

Table 3. shows quantitative surface soil analysis of chemical properties for banana crops with different fertilizers treatments used in premonsoon and postmonsoon season. 


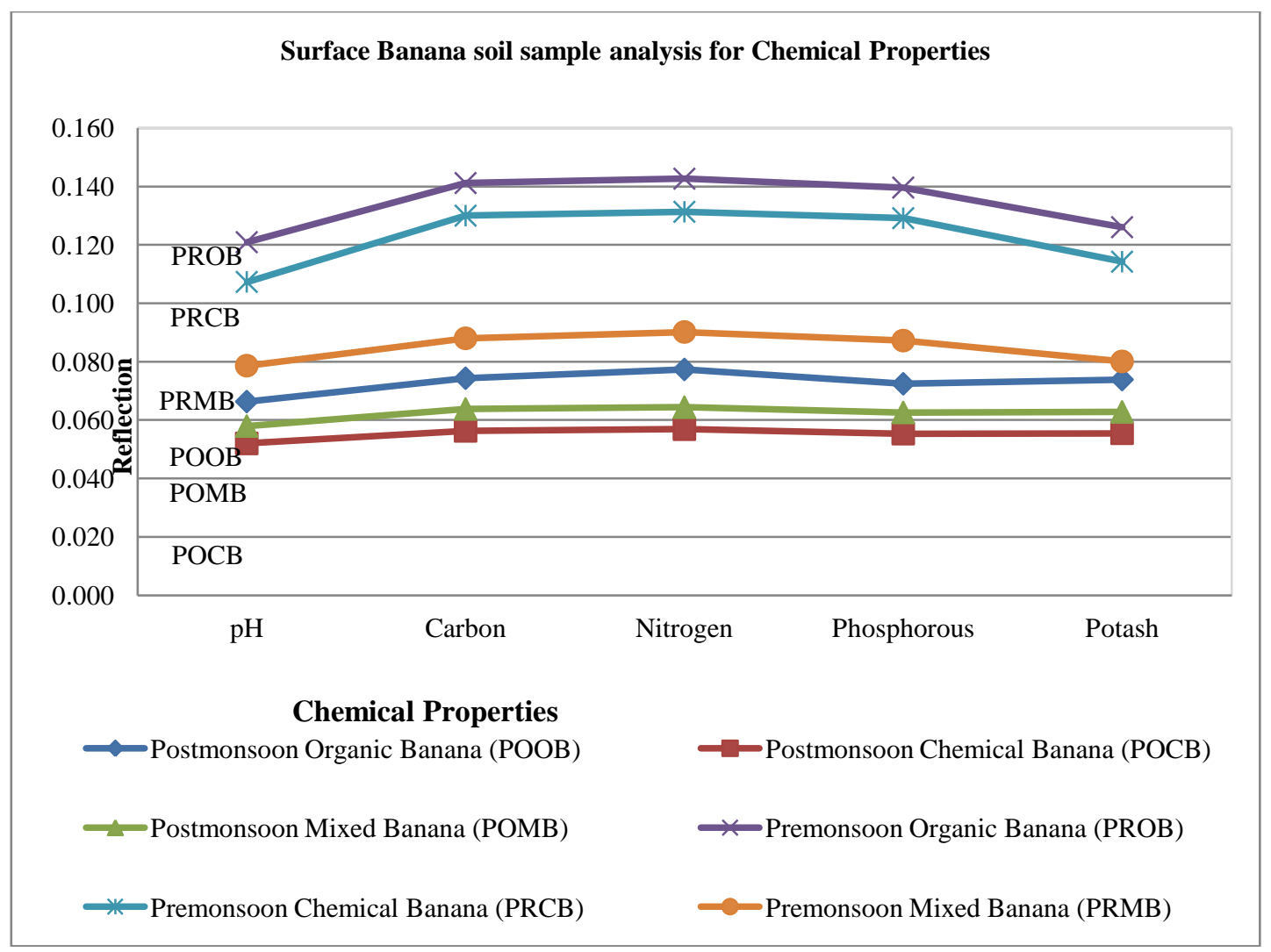

Figure 4. Graphical Representation of Surface Banana soil sample analysis for Chemical Properties

Figure 4 shows surface soil analysis for chemical properties. In this representation of soil analysis Premonsoon organic banana having more reflection means more content availability than chemical banana soil samples and miexed banana soil samples in premonsoon season. In postmonsoon season soil analysis having more reflection for organic banana than postmonsoon mixed banana and chemical banana soil samples. There are more reflection is recorded in premonsoon than postmonsoon season soil samples.

Table 4. shows quantitative subsurface soil analysis of chemical properties for banana crops with different fertilizers treatments used in premonsoon and postmonsoon season.

Table 4. Subsurface Banana soil sample analysis for Chemical Properties
\begin{tabular}{|l|l|l|l|l|l|}
\hline $\begin{array}{l}\text { Season/ Soil } \\
\text { Properties }\end{array}$ & pH & Carbon & Nitrogen & Phosphorous & Potash \\
\hline $\begin{array}{l}\text { Postmonsoon } \\
\text { Organic Banana } \\
\text { (POOB) }\end{array}$ & 0.066 & 0.074 & 0.077 & 0.072 & 0.074 \\
\hline $\begin{array}{l}\text { Premonsoon } \\
\text { Organic Banana } \\
\text { (PROB) }\end{array}$ & 0.121 & 0.141 & 0.143 & 0.140 & 0.126 \\
\hline $\begin{array}{l}\text { Postmonsoon Mixed } \\
\text { Banana (POMB) }\end{array}$ & 0.058 & 0.064 & 0.064 & 0.063 & 0.063 \\
\hline $\begin{array}{l}\text { Premonsoon Mixed } \\
\text { Banana (PRMB) }\end{array}$ & 0.079 & 0.088 & 0.090 & 0.087 & 0.080 \\
\hline $\begin{array}{l}\text { Postmonsoon Banana } \\
\text { Chemical Banan } \\
\text { POCB) }\end{array}$ & 0.052 & 0.056 & 0.057 & 0.055 & 0.055 \\
\hline $\begin{array}{l}\text { Premonsoon } \\
\text { Chemical Banana } \\
\text { (PRCB) }\end{array}$ & 0.107 & 0.130 & 0.131 & 0.129 & 0.114 \\
\hline
\end{tabular}




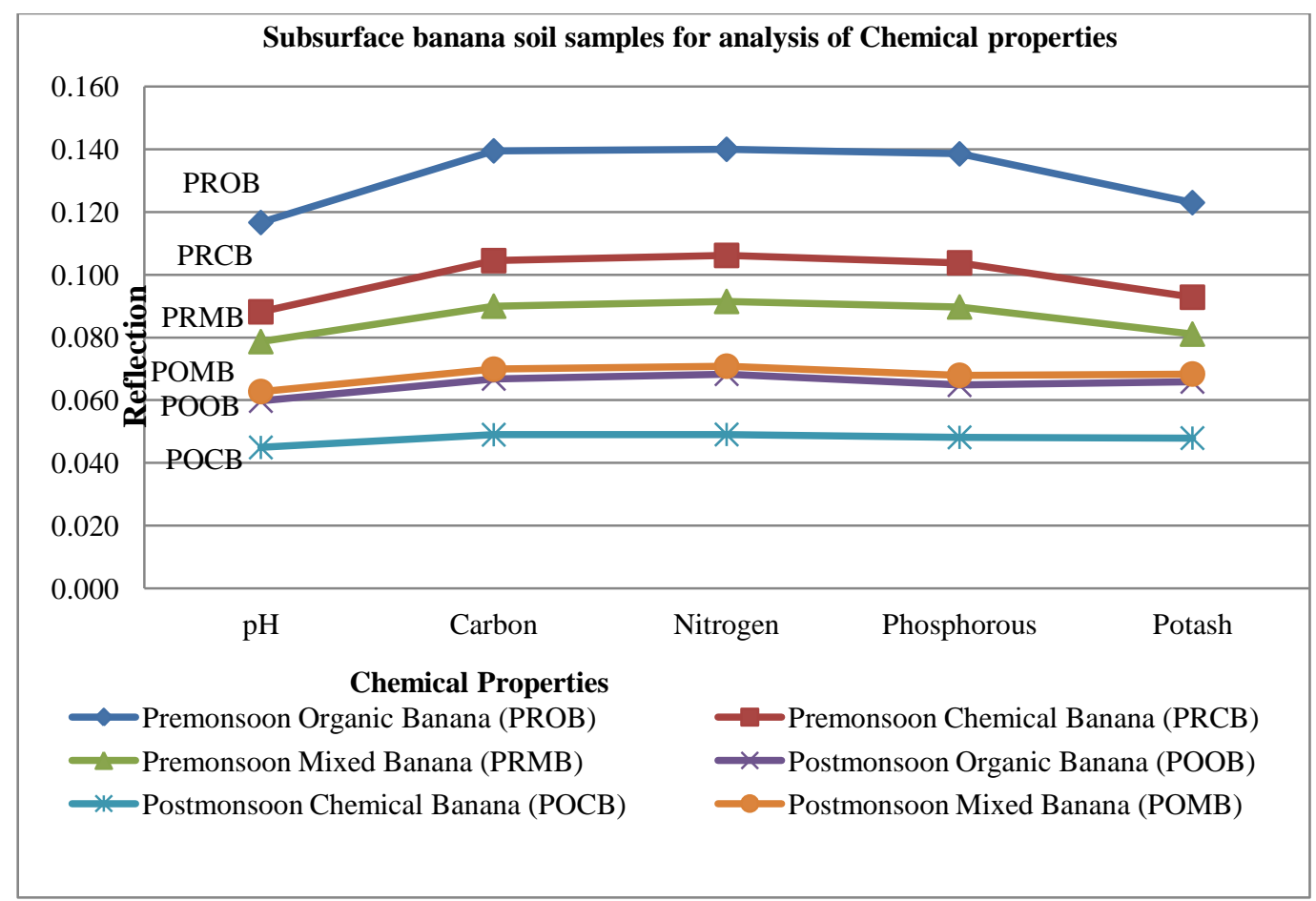

Figure 5. Graphical Representation of Subsurface banana soil samples for analysis of Chemical properties

Figure 5 shows subsurface soil analysis for chemical properties. In this representation of soil analysis Premonsoon organic banana having more reflection means more content availability than chemical banana soil samples and miexed banana soil samples in premonsoon season. In postmonsoon season soil analysis having more reflection found in organic banana soil samples than postmonsoon mixed banana and chemical banana soil samples. There is no more difference is recorded in surface and subsurface soil sample for chemical properties analysis but there are more reflection is recorded in premonsoon than postmonsoon season soil samples and very less chemical properties found in postmonsoon chemical banana soil samples than other fertilizers treatment soil samples.

\subsection{Soil Sample analysis for Physical Properties}

In physical properties sand, silt and clay content are calculated for soil texture analysis. soil properties, texture as an essential characteristic plays a crucial role in soil resistance to rain erosive factors and affects water movement and soil fertility [10] . SOM and moisture contents are also calculated. Table 5. shows quantitative surface soil analysis of physical properties for cotton crops with different fertilizers treatments used in premonsoon and postmonsoon season.

Table 5. Surface Cotton soil sample analysis for Physical Properties

\begin{tabular}{|l|l|l|l|l|l|}
\hline $\begin{array}{l}\text { Season/ Soil } \\
\text { Properties }\end{array}$ & Sand & Silt & Clay & SOM & Moisture \\
\hline $\begin{array}{l}\text { Postmonsoon Organic } \\
\text { Cotton (POOC) }\end{array}$ & 0.061 & 0.061 & 0.063 & 0.038 & 0.062 \\
\hline $\begin{array}{l}\text { Premonsoon Organic } \\
\text { Cotton (PROC) }\end{array}$ & 0.121 & 0.124 & 0.128 & 0.123 & 0.120 \\
\hline $\begin{array}{l}\text { Postmonsoon Mixed } \\
\text { Cotton (POMC) }\end{array}$ & 0.076 & 0.076 & 0.079 & 0.047 & 0.079 \\
\hline
\end{tabular}




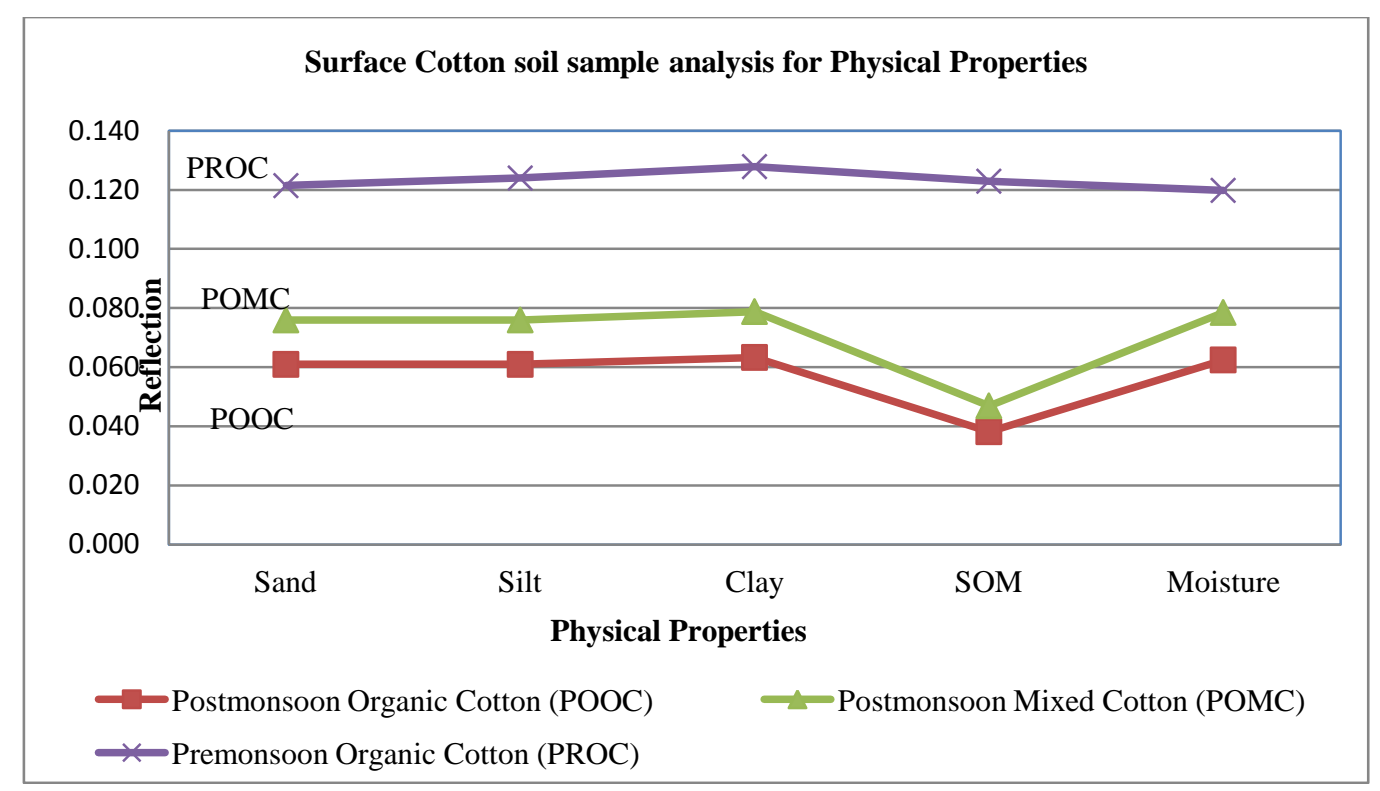

Figure 6. Graphical Representation of Surface Cotton soil sample analysis for Physical Properties

Figure 6 shows Surface cotton soil analysis for Physical Properties. In this category of soil analysis Premonsoon organic cotton soil sample having more reflection means more content availability than postmonsoon mixed cotton and postmonsoon organic cotton soil samples. Premonsoon organic cotton soil having more soil organic matter than postmonsoon mixed cotton soil and organic cotton soil sample.

Table 6. shows quantitative subsurface soil analysis of physical properties for cotton crops with different fertilizers treatments used in premonsoon and postmonsoon season.

Table 6. Subsurface Cotton soil sample analysis for Physical Properties

\begin{tabular}{|l|l|l|l|l|l|}
\hline Season/ Soil Properties & Sand & Silt & Clay & SOM & Moisture \\
\hline $\begin{array}{l}\text { Postmonsoon Organic } \\
\text { Cotton (POOC) }\end{array}$ & 0.051 & 0.051 & 0.053 & 0.033 & 0.052 \\
\hline $\begin{array}{l}\text { Premonsoon Organic } \\
\text { Cotton (PROC) }\end{array}$ & 0.126 & 0.119 & 0.127 & 0.121 & 0.117 \\
\hline $\begin{array}{l}\text { Postmonsoon Mixed } \\
\text { Cotton (POMC) }\end{array}$ & 0.071 & 0.071 & 0.074 & 0.049 & 0.072 \\
\hline
\end{tabular}

\section{Subsurface Cotton soil sample analysis for Physical Properties}

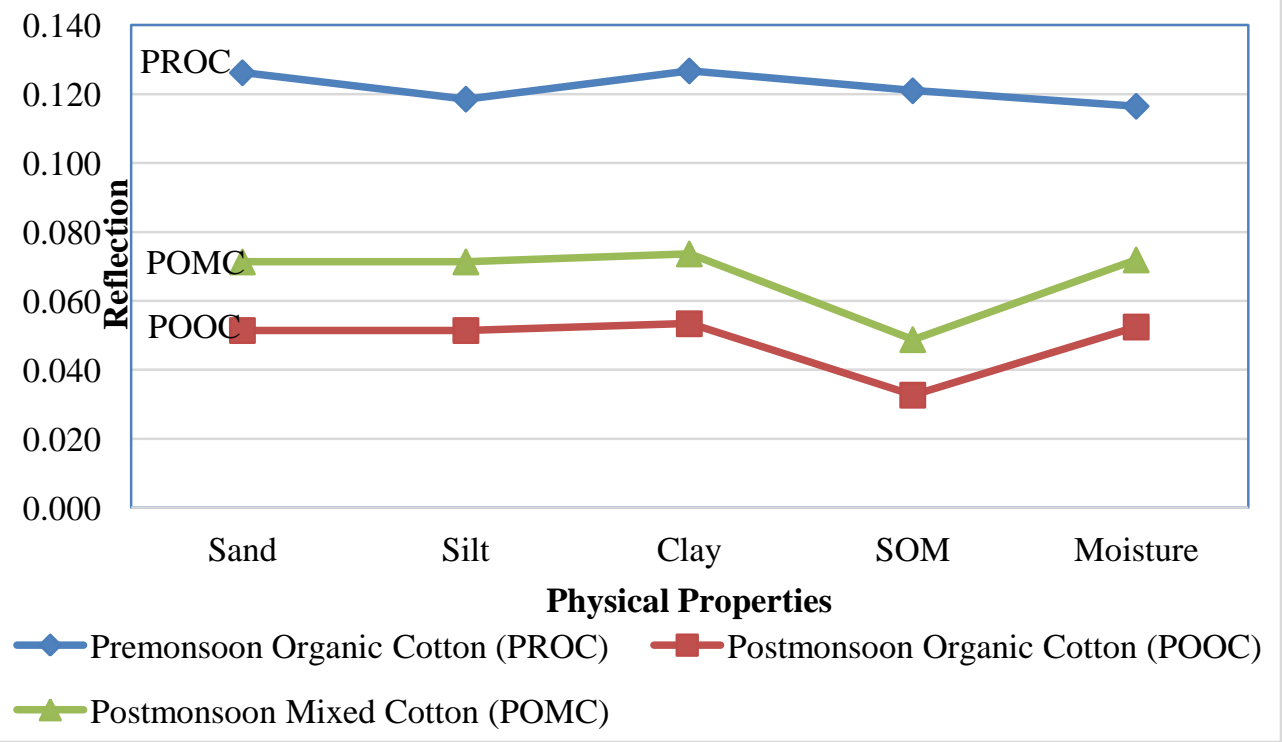

Figure 7. Graphical Representation of Subsurface Cotton soil sample analysis for Physical Properties 
Figure 7 shows subsurface cotton soil analysis for physical properties. In this category of soil analysis premonsoon organic cotton soil sample having more reflection means more content availability than postmonsoon mixed cotton and postmonsoon organic cotton soil samples. There is no more difference is recorded in surface and subsurface soil samples but more difference is found in premonsoon and postmonsoon season. Premonsoon season soil sample having more reflection found than postmonsoon soil samples.

Table 7. shows quantitative surface soil analysis of physical properties for banana crops with different fertilizers treatments used in premonsoon and postmonsoon season.

Table 7. Surface Banana soil sample analysis for Physical Properties

\begin{tabular}{|c|c|c|c|c|c|}
\hline $\begin{array}{c}\text { Season/ Soil } \\
\text { Properties }\end{array}$ & Sand & Silt & Clay & SOM & Moisture \\
\hline $\begin{array}{c}\text { Postmonsoon Organic } \\
\text { Banana (POOB) }\end{array}$ & 0.068 & 0.068 & 0.070 & 0.039 & 0.069 \\
\hline $\begin{array}{c}\text { Premonsoon Organic } \\
\text { Banana (PROB) }\end{array}$ & 0.135 & 0.137 & 0.142 & 0.137 & 0.134 \\
\hline $\begin{array}{c}\text { Postmonsoon Mixed } \\
\text { Banana (POMB) }\end{array}$ & 0.059 & 0.059 & 0.061 & 0.039 & 0.060 \\
\hline $\begin{array}{c}\text { Premonsoon Mixed } \\
\text { Banana (PRMB) }\end{array}$ & 0.086 & 0.087 & 0.088 & 0.086 & 0.085 \\
\hline $\begin{array}{c}\text { Postmonsoon } \\
\text { Chemical Banana } \\
\text { (POCB) }\end{array}$ & 0.052 & 0.052 & 0.054 & 0.038 & 0.053 \\
\hline $\begin{array}{c}\text { Premonsoon Chemical } \\
\text { Banana (PRCB) }\end{array}$ & 0.124 & 0.127 & 0.131 & 0.126 & 0.123 \\
\hline
\end{tabular}

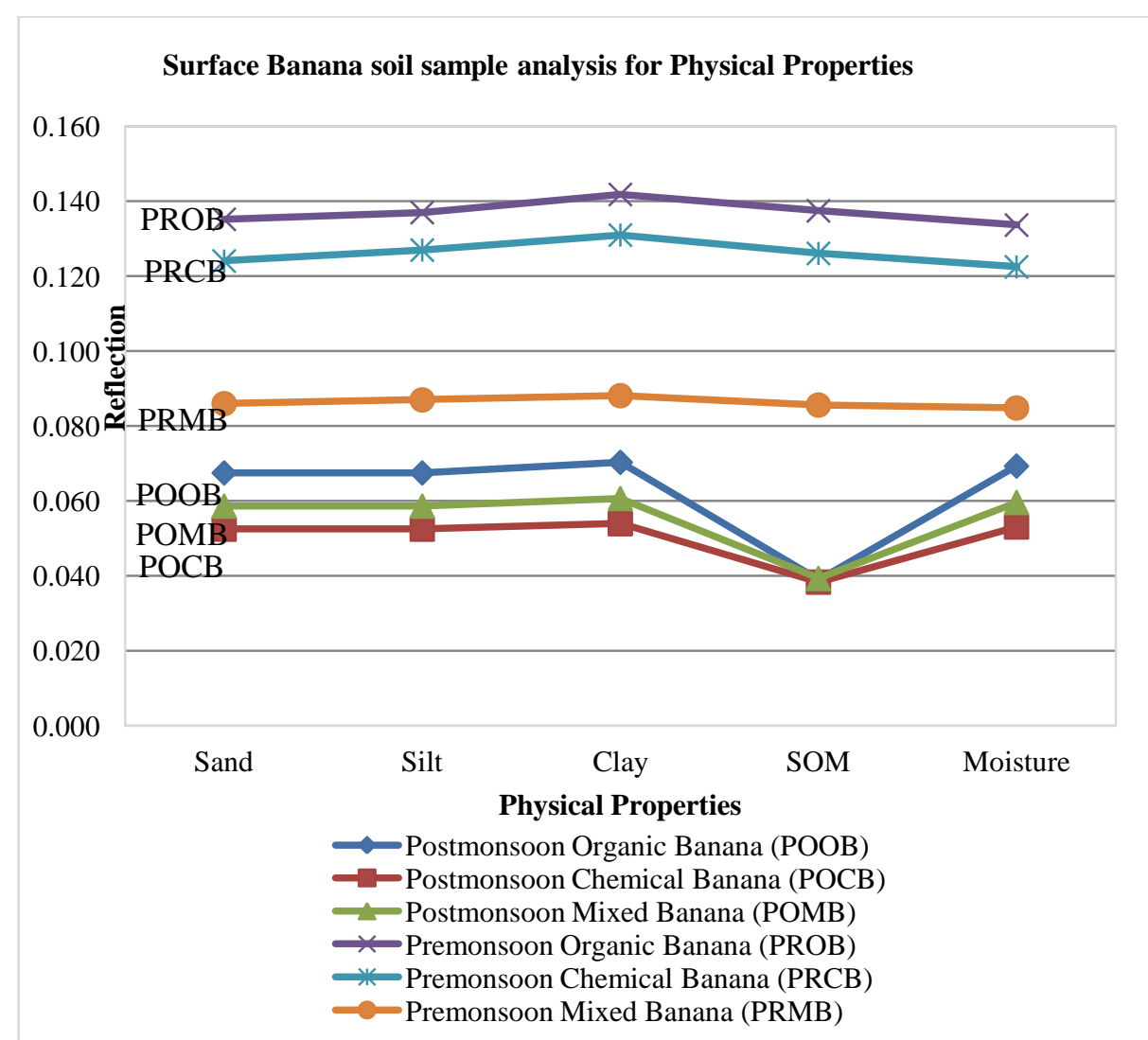

Figure 8. Graphical Representation Surface Banana soil sample analysis for Physical Properties

Figure 8 shows surface soil analysis for physical properties. In this representation of soil analysis Premonsoon organic banana having more reflection means more content availability than chemical banana soil samples and miexed banana soil samples in premonsoon season. In postmonsoon season soil analysis having more reflection for organic banana than postmonsoon mixed banana and chemical banana soil samples. There are more reflection is recorded in premonsoon than postmonsoon season soil samples. In postmonsoon soil sample soil organic matter found almost same in all fertilizers treatment but there is high reflection is found in premonsoon season soil samples.

Table 8.shows quantitative subsurface soil analysis of physical properties for banana crops with different fertilizers treatments used and soil samples are collected in premonsoon and postmonsoon season. 
Table 8. Subsurface Banana soil sample analysis for Physical Properties

\begin{tabular}{|c|c|c|c|c|c|}
\hline $\begin{array}{c}\text { Season/ Soil } \\
\text { Properties }\end{array}$ & Sand & Silt & Clay & SOM & Moisture \\
\hline $\begin{array}{c}\text { Postmonsoon Organic } \\
\text { Banana (POOB) }\end{array}$ & 0.061 & 0.061 & 0.063 & 0.036 & 0.062 \\
\hline $\begin{array}{c}\text { Premonsoon Organic } \\
\text { Banana (PROB) }\end{array}$ & 0.140 & 0.132 & 0.141 & 0.135 & 0.130 \\
\hline $\begin{array}{c}\text { Postmonsoon } \\
\text { Chemical Banana } \\
\text { (POCB) }\end{array}$ & 0.046 & 0.046 & 0.047 & 0.034 & 0.046 \\
\hline $\begin{array}{c}\text { Premonsoon Chemical } \\
\text { Banana (PRCB) }\end{array}$ & 0.105 & 0.101 & 0.105 & 0.102 & 0.099 \\
\hline $\begin{array}{c}\text { Postmonsoon Mixed } \\
\text { Banana (POMB) }\end{array}$ & 0.064 & 0.064 & 0.066 & 0.042 & 0.066 \\
\hline $\begin{array}{c}\text { Premonsoon Mixed } \\
\text { Banana (PRMB) }\end{array}$ & 0.090 & 0.087 & 0.091 & 0.088 & 0.086 \\
\hline
\end{tabular}

Subsurface Banana soil sample analysis for Physical Properties

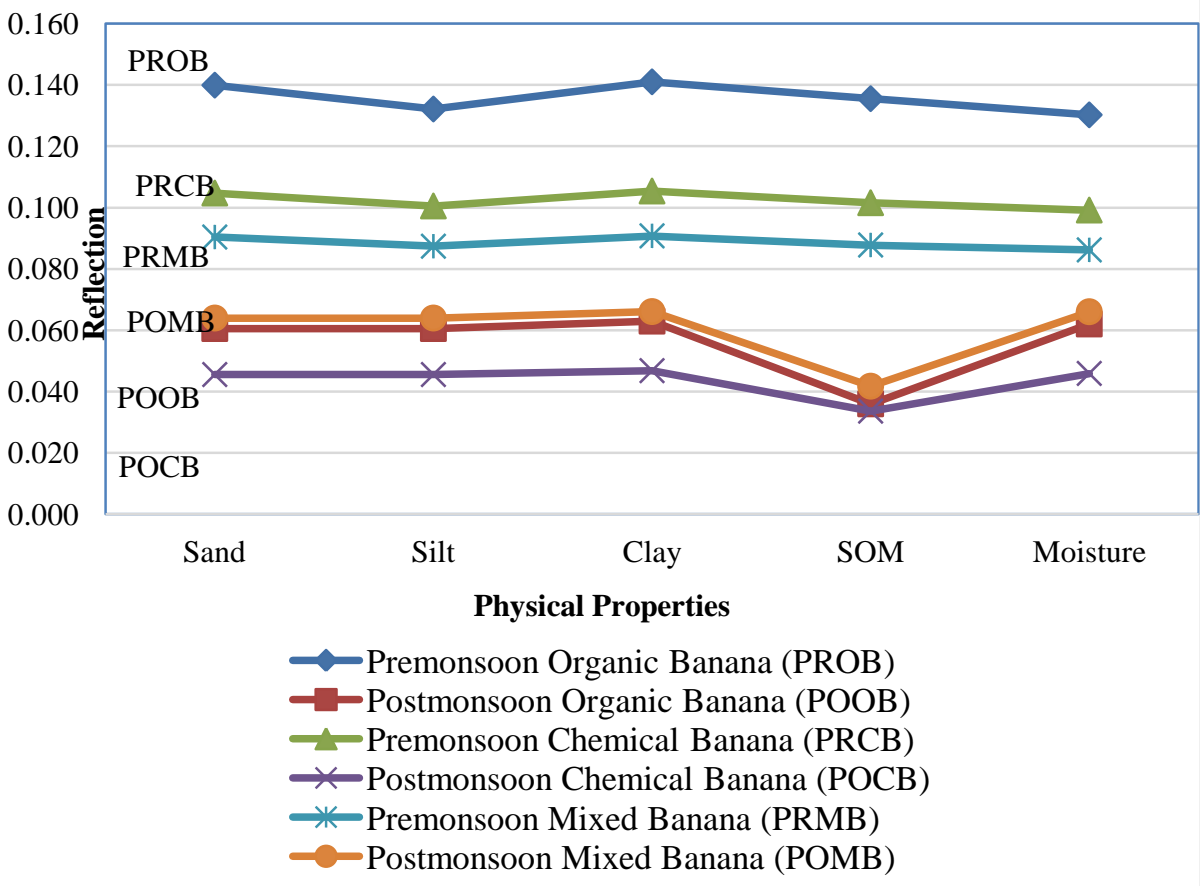

Figure 9. Graphical Representation of Subsurface Banana soil sample analysis for Physical Properties

Figure 9 shows subsurface soil analysis for physical properties. In this representation of soil analysis Premonsoon organic banana having more reflection means more content availability than chemical banana soil samples and miexed banana soil samples in premonsoon season. In postmonsoon season soil analysis having more reflection for organic banana than postmonsoon mixed banana and chemical banana soil samples. There are more reflection is recorded in premonsoon than postmonsoon season soil samples. In postmonsoon soil sample soil organic matter found moderate difference in all fertilizers treatment but there is high reflection is found in premonsoon season soil samples. There is no more difference were found in surface and subsurface soil samples.

\section{CONCLUSIOON}

Remote sensing ground based spectral data is an alternative methods to the traditional methods for soil properties analysis.
In this paper spectral reflection data is acquired using FieldSpech4 Spectroradiometer is used for analysis of different physical and chemical properties. For this study soil samples were collected in premonsoon and postmonsoon season from surface and subsurface. The collected soil sample having different fertilizers treatment used for banana and cotton crops. In this comparative analysis the result shows the influence of fertilizers in different seasons. The surface soil samples physical and chemical properties availability are higher than subsurface soil sample. But it is moderate difference is found in surface and subsurface soil samples. The more content are available in premonsoon season soil sample than postmonsoon season soil samples and Organic fertilizers treatment applied soil samples having more reflection in all category of collected soil samples. Thus, these indicated that organic fertilizers should be recommended to improve soil quality and soil fertility. The remote sensing ground based spectral data 
collection and analysis method is innovative and fast technique for soil analysis. This study is useful for farmers to understand the soil content variability, effect of fertilizers on soil in different season as well as it is useful for fertilizers treatment management. It is useful for reducing the unnecessary fertilizers and directly it is helpful to reducing the fertilizers cost as well as it is important for soil fertility and productivity.

\section{REFERENCES}

[1] Okoffo E. D., Ofori A., Nkoom M., Bosompem O.A., “ Assessment of the physicochemical Characterristics of soils in major Cocoa producing areas in the dormaa west district of Ghana", International Journal of Scientific \& Technology Research , Vol. 5, issue 02, feb. 2016, PP. 6268

[2] Vipin Y. Borole, Sonali B. Kulkarni, Pratibha R. Bhise, "Effect of fertilizers on soil properties for different crops in pre-monsoon season using spectroradiometer for raver tehsil of jalgaon district", International Journal of Scientific and Technology Research, Volume 9, Issue 2, February 2020, PP. 844-849

[3] Suzana Romeiro Araujo, Jose Alexandre Melo Dematte, Henrique Bellinaso, "Analysing the effect of applying agricultural lime to soils by VNIR spectral sensing:a quantitative and quick method", International Journal of Remote sensing, Tylor \&Francis, Vol.34, no. 13, PP. 4570-4584

[4] Huan Yu, Bo Kong, Guangxing Wang, Rongxiang Du, Guangping Qie, "Prediction Of Soil Properties Using A Hyperspectral Remote Sensing Method", Archives Of Agronomy And Soil Science, Taylor \& Francis Group, 2017

[5] Tarik Mitran, T. Ravisankar, M.A. Fyzee, Janaki Rama Suresh, G. Sujatha \& K. Sreenivas, "Retrieval of soil physicochemical properties towards assessing saltaffected soils using Hyperspectral Data", Geocarto International, 30:6,2015, PP.701-721

[6] Naxin Cui, Min Cai, Xu Zhang, Ahmed A. Abdelhafez, Li Zhou, Huifeng Sun, Guifa Chen, Guoyan Zou, Sheng Zhou, "Runoff loss of nitrogen and phosphorus from a rice paddy field in the east of China: Effects of long-term chemical $\mathrm{N}$ fertilizer and organic manure applications", Global Ecology and Conservation, Elsevier,22 , March 2020, PP.1-12

[7] Bhise Pratibha.R, Kulkarni Sonali.B "Remote Sensing and Data Mining Techniques Applied on Soil Characteristics Data Classification", IOSR Journal of Computer Engineering (IOSR-JCE), PP. 83-91

[8] P.R. Bhise, S.B. Kulkarni, "Evaluation of Soil Physical/Chemical Parameters for Agriculture Production in Vaijapur Taluka Using VNIR-SWIR Reflectance Spectroscopy", International Journal of Computer Sciences and Engineering, Vol.-6, Issue-12, Dec 2018, PP. 43-48

[9] Vipin Y. Borole, Sonali B. Kulkarni, "Soil quality assessment for analyzing the effect of chemical fertilizers on agriculture field using Spectroradiometer: A review", International Conference on Electrical, Communication, Electronics, Instrumentation and Computing (ICECEIC), IEEE, 2019

[10] Mansour Chaternour, Ahmad Landi, Ahmad Farrokhian Firouzi, Aliakbar Noroozi, Hosseinali Bahrami, "Spectral behavior modeling of soil texture over dust center of Khuzestan Province using hyperspectral images and Random Forest (RF) model", Vol 9 (4), Oct 2019, PP.466-479

[11] Ramdas D. Gore, Sunil S. Nimbhore, Bharti W.Gawali, "Understanding Soil Spectral Signature Though RS and GIS Techniques", International Journal of Engineering Research and General Science Volume 3, Issue 6, November-December, 2015, pp. 866-872

[12] Pratibha R.Bhise, Sonali B.Kulkarni, "Estimation of Soil Macronutrients From Spectral Signatures Using Hyperspectral Non-Imaging Data”, International Conference on Electrical, Communication, Electronics, Instrumentation and Computing (ICECEIC), IEEE, 2019

[13] Pratibha R.Bhise , Sonali B.Kulkarni, "Review on Analysis and Classification Techniques of Soil Study in Remote Sensing and Geographic Information System", International Journal of Emerging Trends \& Technology in Computer Science (IJETTCS), Volume 6, Issue 1, pp.124-138

[14] Pratibha R.Bhise , Sonali B.Kulkarni, Vipin Y. Borole.," Preprocessing and statistical analysis of soil parameters using conventional laboratory techniques and nonimaging spectral techniques for Vaijapur taluka", International Journal of Recent Technology and Engineering, Volume 8, Issue 2, July 2019, PP. 30923096

[15] Tiezhu Shi, Junjie wang, Huizeng Liu, Guofeng Wu, "Estimating leaf nitrogen concentration in heterogeneous crop plants from hyperspectral reflectance", International Journal of Remote Sensing, Vol. 36, No. 18, Oct 2015 , PP.4652-4667

[16] Nataliia Ridei, Vita Strokal, Maryna Strokal, "Soil Quality classes for characterizing the soil potential to produce biologically and ecologically valuable crops", Archives of Agronomy and soil Science, Vol. 58, No. S1. Oct 2012 PP. 219-225

[17] Vipin Y. Borole, Sonali B. Kulkarni, Pratibha R. Bhise, "Soil spectral signature analysis for influence of fertilizers on two differen crops in raver Tahshil", International Journal of Recent Technology and Engineering, Volume8, Issue-3, Sep-2019, pp. 659-663

[18] Ramdas D. Gore, Reena H. Chaudhari, and Bharti W. Gawali , "Creation of Soil Spectral Library for Marathwada Region", International Journal of Advanced Remote Sensing and GIS, Volume 5, Issue 6,2016, pp. 1787-1794

[19] GUO Wei, Mathias N Andersen, QI Xue-bin, LI Ping, LI Zhong-yang, FAN Xiang-yang, ZHOU Yuan, "Effects of reclaimed water irrigation and nitrogen fertilization on the chemical properties and microbial community of soil", Journal of Integrative Agriculture, Elsevier, Volume16, issue 3, 2017, PP, 679-690

[20] Offer Rozenstein, Tarin Paz-Kagan, Christoph Salbach, and Arnon Karnieli, "Comparing the Effect of Preprocessing Transformations on Methods of Land-Use Classification Derived From Spectral Soil Measurements", IEEE Journal Of Selected Topics In Applied Earth Observations And Remote Sensing, PP 112

[21] Talli Ilani, Ittai Herrmann, Arnon Karnieli, Gilboa Arye, 
"Characterization of the biosolids composting process by hyperspectral analysis", Elsevier Ltd., Waste Management 48, 2016, pp.106-114

[22] Haijun Qi, Tarin Paz-Kagan, Arnon Karnieli, Shaowen Li, "Linear Multi-Task Learning for Predicting Soil Properties Using Field Spectroscopy”, Remote Sens. 2017

[23] Haijun Qi, Tarin Paz-Kagan, Arnon Karnieli, Xiu Jin, Shaowen Li, "Evaluating calibration methods for predicting soil available nutrients using hyperspectral VNIR data", Soil \& Tillage Research, issue 175, 2018, pp.267-275

[24] Vipin Y. Borole, Sonali B. Kulkarni, "Spectral data analysis methods for soil properties assessment using remote sensing", IOSR Journal of Computer Engineering (IOSR-JCE), Volume 23, Issue 1, Jan. - Feb. 2021, PP 1418
[25] S.K. Reza, D.C. Nayak, T. Chattopadhyay, S. Mukhopadhyay, S.K. Singh \& R. Srinivasan, "Spatial distribution of soil physical properties of alluvial soils: a geostatistical approach",Archives Of Agronomy And Soil Science, Taylor \& Francis, Vol. 62, NO. 7, Page No. 972981,2016

[26] Amol D. Vibhute, K. V. Kale, Rajesh K. Dhumal, S. C. Mehrotra, "Soil Type Classification and Mapping using Hyperspectral Remote Sensing Data", International Conference on Man and Machine Interfacing (MAMI), IEEE, 2015 .

[27] Vipin Y.Borole, Sonali B.Kulkarni, Pratibha R. Bhise." Soil Properties Assessment In Surface And Subsurface Using Spectroradiometer For Raver Tehsil Of Jalgaon District", Journal of critical reviews 7(18), 2020, PP. 2487-2495 